\title{
Urinary human polyomavirus and papillomavirus infection and bladder cancer risk
}

\author{
J Polesel', T Gheit ${ }^{2}$, R Talamini', N Shahzad ${ }^{2}$, O Lenardon ${ }^{3}$, B Sylla ${ }^{2}$, C La Vecchia ${ }^{4,5}$, D Serraino', \\ $M$ Tommasino $^{2}$ and S Franceschi*,2 \\ 'Unit of Epidemiology and Biostatistics, IRCCS Centro di Riferimento Oncologico, 3308 I Aviano (PN), Italy; ${ }^{2}$ International Agency for Research \\ on Cancer, 150 Cours Albert Thomas, 69372 Lyon Cedex 08, France; ${ }^{3}$ Unit of Urology, Azienda Ospedaliera Santa Maria degli Angeli, 33 I 70 Pordenone \\ (PN), Italy; ${ }^{4}$ Department of Epidemiology, The Mario Negri Institute for Pharmacological Research, 20156 Milan, Italy; ${ }^{5}$ Department of Occupational \\ Medicine, Università degli Studi di Milano, 20133 Milan, Italy
}

\begin{abstract}
BACKGROUND: The association of transitional cell carcinomas of the bladder (TCB) with Schistosoma haematobium suggested a possible role of infections in the aetiology of TCB.

METHODS: In all, II4 TCB cases and I40 hospital controls from Pordenone Province were enrolled within an Italian multi-centric case-control study. Urine samples were screened for DNA from five human polyomaviruses (HPyV) (JCV, BKV, MCV, WUV, and KIV); SV40; and 22 mucosal human papillomaviruses (HPV) using highly sensitive PCR assays. Odds ratios (ORs) and corresponding confidence intervals (Cls) were computed for risk of TCB by HPyV-or HPV-positivity using unconditional logistic regression. RESULTS: Human polyomavirus prevalence was similar in TCB cases (7I.7\%) and controls (77.7\%) (OR for TCB =0.85; $95 \%$ Cl: $0.45-$ I.6I). JCV was the most frequently detected HPy type. No individual HPy showed a significant association. Among cases, HPy $\mathrm{H}$ positivity was not associated with tumour characteristics, but it was significantly lower in women than men and among current and former smokers than never smokers. Human papillomavirus was detected in seven cases and five controls $(\mathrm{OR}=1.52 ; 95 \% \mathrm{Cl}$ : $0.42-5.45)$.

CONCLUSION: The present small study does not support an involvement of HPyV or HPV infection in TCB aetiology in immunocompetent individuals. Differences in HPyV-positivity by sex and smoking may derive from differences in either acquisition or persistence of the infection.

British Journal of Cancer (2012) 1 06, 222-226. doi: I0.1038/bjc.20II.519 www.bjcancer.com

Published online 24 November 2011

(C) 2012 Cancer Research UK
\end{abstract}

Keywords: human polyomavirus; human papillomavirus; bladder cancer

Incidence rates of bladder cancer in Italian men are among the highest worldwide (Ferlay et al, 2010). Tobacco smoking and exposure to aromatic amines, ionising radiation, and cyclophosphamide are well-established risk factors for bladder cancer (Silverman et al, 2006). The associations with Schistosoma haematobium (Bedwani et al, 1998) and kidney transplantation (Vajdic et al, 2006) and the possible association with recurrent urinary tract infections (La Vecchia et al, 1991) raised interest in a possible role of infectious agents, including the mucosal human papillomavirus (HPV) types that are responsible for the vast majority of cancers of the anogenital tract (IARC, 2007), and, more recently, human polyomaviruses (HPyV) (Barbanti-Brodano et al, 2006; Rollison et al, 2007; Roberts et al, 2008).

Five $\mathrm{HPyV}$ have been known for some time (i.e., JCV, BKV, MCV, WUV, and KIV) and four additional types have been recently characterised (Johne et al, 2011; Scuda et al, 2011). BKV has been most intensively studied in relation to bladder cancer as its major sites of persistence are the cells of the kidney and urinary tract (Jiang et al, 2009) and it induces nephropathy in renal

*Correspondence: Dr S Franceschi; E-mail: franceschis@iarc.fr Received 10 June 20 I I; revised 28 October 201 I; accepted 2 November 20I I; published online 24 November 20I I transplant patients. Both BKV and JCV were detected in the urine of a substantial proportion of immunosuppressed and immunocompetent individuals (Jiang et al, 2009). Most previous work on HPyV (Geetha et al, 2002; Fioriti et al, 2003; Weinreb et al, 2006) or HPV (IARC, 2007) and bladder cancer consisted, however, of small-sized case series that did not include any comparison group or relied on antibody seroprevalence only (Newton et al, 2005).

To further evaluate the possible role of viral infections in bladder cancer, we carried out the first case-control study on the relationship between bladder cancer risk and the presence of $\mathrm{HPyV}$ in urine samples. The presence of HPV DNA in bladder cancer cases and controls was also compared.

\section{MATERIALS AND METHODS}

\section{Study subjects}

The present report deals with the first cases of transitional cell carcinoma of the bladder (TCB) and control subjects consecutively enrolled in the province of Pordenone between August 2004 and July 2007 within the framework of an on-going multi-centric casecontrol study of TCB. 
Cases $(n=124)$ were patients above 18 years of age with incident histologically or cytologically confirmed TCB admitted to major general hospitals in the study area. Controls $(n=151)$ were patients admitted for a wide spectrum of acute conditions to the same hospitals where cases had been interviewed. Subjects admitted for diseases related to tobacco smoking or alcohol consumption, or any disorder that might have induced long-term modification of diet were excluded from the control group. The reasons for hospital admission among controls were traumatic orthopaedic disorders (36.4\%); other orthopaedic disorders (28.6\%); acute surgical conditions $(27.9 \%)$; and a range of other illnesses, including nose, ear, skin, or dental disorders (7.1\%). Refusal rate was below $5 \%$ in either cases and controls. Transplant recipients were ineligible as cases or controls and there was no indication of severe immunosuppression in the medical records of any of the study subjects. All study subjects signed an informed consent, according to the recommendations of the Board of Ethics of the study hospitals.

\section{Questionnaire and biological samples}

Trained interviewers administered a structured questionnaire to cases and controls during their hospital stay. The questionnaire collected information on socio-demographic factors, lifestyle habits, diet, a problem-oriented medical history, family history of cancer, occupational history, exposure to selected carcinogens, and hair dye use. Detailed information on lifetime history of tobacco smoking and alcohol drinking was elicited and validated (D’Avanzo et al, 1996).

We collected a 50-ml sample of first-voided urine before study subjects had undergone any treatment. Standard clean-catch procedures for urine collection were applied to prevent sample contamination. Half of the sample $(25 \mathrm{ml})$ was stored at $-80^{\circ} \mathrm{C}$ and the remaining $25 \mathrm{ml}$ were put in CytoLyt solution and stored at $4{ }^{\circ} \mathrm{C}$.

\section{DNA extraction}

Urine samples in CytoLyt solution were concentrated using the Amicon Ultra-15 centrifugal filters (Millipore Corp., Bedford, MA, USA). In all, $15 \mathrm{ml}$ of urine was added to the filter unit for a centrifugation at $4000 \mathrm{~g}$ for $15 \mathrm{~min}$. After centrifugation, DNA extraction was performed using the MagNA Pure Compact robot (Roche Diagnostics GmbH, Mannheim, Germany) with the nucleic acid isolation kit I - large volume according to the manufacturer's instructions. To monitor the possible occurrence of crosscontamination between the different specimens during DNA extraction, tubes containing water only were also included and blindly processed in the following steps of the study. The DNA quality of samples was checked by amplifying a fragment of the $\beta$-globin gene using Hot Start PCR, performed according to the standard protocols. All analyses were carried out under conditions of pre- and post-PCR separation.

\section{Polyomavirus typing}

Multiplex PCR conditions First, urine samples were screened using a multiplex PCR-based assay that identified the presence of any of five $\mathrm{HPyV}$ (JCV, BKV, MCV, WUV, and KIV) and one simian PyV (SV40). Six pairs of specific primers were designed in order to amplify a fragment of the Large $\mathrm{T} \mathrm{Ag}$ gene of $253 \mathrm{bp}$ for MCV and $256 \mathrm{bp}$ for the other HPyV and SV40 (sequences available upon request). The accession numbers of the GenBank sequences that we used as references, with the corresponding HPyV given in parentheses, were NC_009539 (WUV), EF520287 (KIV), NC_001699 (JCV), NC_001538 (BKV), EU375804 (MCV), and NC_001669 (SV40). Oligonucleotides were synthesised by MWG Biotech (Ebersberg, Germany).
Forty amplification cycles were run in a GeneAmp PCR System 2700 (Applied Biosystems, Weiterstadt, Germany) with a $94^{\circ} \mathrm{C}$ denaturation step for $30 \mathrm{~s}$, a $63^{\circ} \mathrm{C}$ annealing step for $3 \mathrm{~min}$, and a $72^{\circ} \mathrm{C}$ extension step for $1.30 \mathrm{~min}$, including an initial denaturation step of $15 \mathrm{~min}$ at $95^{\circ} \mathrm{C}$ and a final extension step of $10 \mathrm{~min}$ at $72^{\circ} \mathrm{C}$. The $25-\mu$ l reactions comprised $1 \times$ multiplex PCR Kit buffer (Qiagen, Hilden, Germany), containing $3 \mathrm{~mm} \mathrm{MgCl}_{2}$, dNTP mix and HotStartTaq DNA polymerase, $0.2 \mu \mathrm{moll}^{-1}$ of each primer, and $10 \mu \mathrm{l}$ of DNA. In all, $5 \mu \mathrm{l}$ of the PCR products was checked by ethidium bromide agarose gel electrophoresis.

In order to evaluate the sensitivity of our assay, a multiplex PCR was performed using serial dilutions of DNA (from 1000 to 0 copies of viral genome) from HPyV types and SV40 as template. A PCR was positive down to 10 copies of viral genome. The presence of a large number of primers in the multiplex PCR, therefore, did not hamper the sensitivity of the assay. In order to evaluate specificity, human genomic DNA was mixed with individual HPyV genomes and tested in the multiplex PCR. The test was positive when HPyV DNA was included, while it was always negative when human genomic DNA only was used as template (data not shown). In addition, the specificity of present findings was further strengthened by direct DNA sequencing of HPyV PCR fragments.

Sequencing In order to identify individual HPyV types and SV40, all samples that were positive by multiplex PCR were sequenced. After enzymatic purification with $0.4 \mu \mathrm{l}$ of Exonuclease $\mathrm{I}\left(10 \mathrm{U} \mathrm{ml}^{-1}\right)$ (New England Biolabs, Hertfordshire, UK) and $0.2 \mu$ l of Shrimp Alkaline Phosphatase ( $1 \mathrm{U} \mathrm{ml}^{-1}$ ) (USB Corp., Cleveland, OH, USA) at $37^{\circ} \mathrm{C}$ for $15 \mathrm{~min}$ and an inactivation step at $80^{\circ} \mathrm{C}$ for $15 \mathrm{~min}$, the PCR products were sequenced by the fluorescent dye dideoxy termination method using an ABI Prism 377 DNA sequencer (PE Applied Biosystems, Foster City, CA, USA). For the sequencing reaction, the same primers were used as for the PCR reaction.

\section{HPV typing}

The detection of HPV DNA was performed using a highly sensitive and specific assay recently developed in our laboratory using a multiplex PCR combined to the Luminex suspension array technology (Luminex Corp., Austin, TX, USA). This assay is able to detect 19 mucosal high-risk and potential high-risk HPV types $(16,18,26,31,33,35,39,45,51,52,53,56,58,59,66,68 \mathrm{a}, 70,73$, and 82) (Gheit et al, 2006; Schmitt et al, 2010). Another type of HPV68 (68b) and two mucosal low-risk HPV types (HPV6 and HPV11) were recently added to the assay.

\section{Statistical analysis}

The present analyses were restricted, according to the virus under evaluation, to (1) $\beta$-globin-positive subjects (96 cases and 96 controls); and (2) $\beta$-globin-negative subjects who were positive for HPyV DNA (17 cases and 43 controls) or HPV DNA (one case and four controls). For HPyV analyses, 113 cases (median age: 67 years; range: $37-79$ years) and 139 controls (median age: 67 years; range: 36-78 years) were considered. Conversely, 97 cases (median age: 68 years; range: $37-79$ years) and 100 controls were included in HPV analyses (median age: 68 years; range: $36-78$ years). Odds ratios (ORs) for TCB and for HPyV-positivity or HPV-positivity and their corresponding $95 \%$ confidence intervals (CIs) were calculated by means of unconditional logistic regression models (Breslow and Day, 1980), adjusted for sex, age, education, alcohol drinking, and smoking habits as reported in Tables 1-4.

\section{RESULTS}

Transitional cell carcinoma of the bladder cases and controls reported similar education level (Table 1). Smoking was strongly 
Table I Distribution of II4 bladder cancer cases and 140 hospita controls according to socio-demographic characteristics and selected variables

\begin{tabular}{|c|c|c|c|}
\hline & $\begin{array}{l}\text { Cases } \\
n(\%)\end{array}$ & $\begin{array}{c}\text { Controls } \\
\text { n (\%) }\end{array}$ & OR $(95 \% \mathrm{Cl})^{a}$ \\
\hline \multicolumn{4}{|l|}{ Sex } \\
\hline Men & $95(83.3)$ & II $4(81.4)$ & \\
\hline Women & $19(16.7)$ & $26(18.6)$ & \\
\hline \multicolumn{4}{|l|}{ Age (years) } \\
\hline$<65$ & $42(36.8)$ & $50(35.7)$ & \\
\hline $65-74$ & $43(37.7)$ & $61(43.6)$ & \\
\hline$\geqslant 75$ & $29(25.4)$ & $29(20.7)$ & \\
\hline \multicolumn{4}{|l|}{ Education (years) } \\
\hline$<7$ & $54(47.4)$ & $7 \mid(50.7)$ & Ref. \\
\hline $7-11$ & $40(35.1)$ & $44(31.4)$ & $1.27(0.68-2.38)$ \\
\hline$\geqslant 12$ & $20(17.5)$ & $25(17.9)$ & $1.12(0.50-2.49)$ \\
\hline$\chi^{2}$ for trend & & & $0.19 ; P=0.66$ \\
\hline \multicolumn{4}{|l|}{ Smoking habit } \\
\hline Never & $15(13.2)$ & $45(32.1)$ & Ref. \\
\hline Former & $54(47.4)$ & 77 (55.0) & $2.25(1.10-4.60)$ \\
\hline Current & $45(39.5)$ & $18(12.9)$ & $9.15(3.92-21.37)$ \\
\hline \multicolumn{4}{|c|}{ Intensity (cig per day) ${ }^{\mathrm{b}}$} \\
\hline$<15$ & $13(11.4)$ & $8(5.7)$ & $4.92(1.64-14.73)$ \\
\hline$\geqslant 15$ & $32(28.1)$ & $10(7.1)$ & $11.23(4.00-31.53)$ \\
\hline$\chi^{2}$ for trend & & & $22.08 ; P<0.01$ \\
\hline \multicolumn{4}{|c|}{ Drinking habit (drinks per week) } \\
\hline$<21$ & $43(37.7)$ & $65(46.4)$ & Ref. \\
\hline$\geqslant 21$ & 7I (62.3) & 75 (53.6) & $1.60(0.87-2.95)$ \\
\hline
\end{tabular}

Abbreviations: $\mathrm{Cl}=$ confidence interval; $\mathrm{OR}=$ odds ratio. ${ }^{\mathrm{a}}$ Estimated from unconditional logistic regression, adjusted for sex, age, education, and smoking habit, as appropriate. ${ }^{b}$ Among current smokers only.

Table 2 Odds ratios (ORs) of bladder cancer and corresponding 95\% confidence intervals (Cls) by prevalence of DNA from human polyomaviruses (HPyV), simian virus 40 (SV40), or human papillomavirus (HPV) in the urine

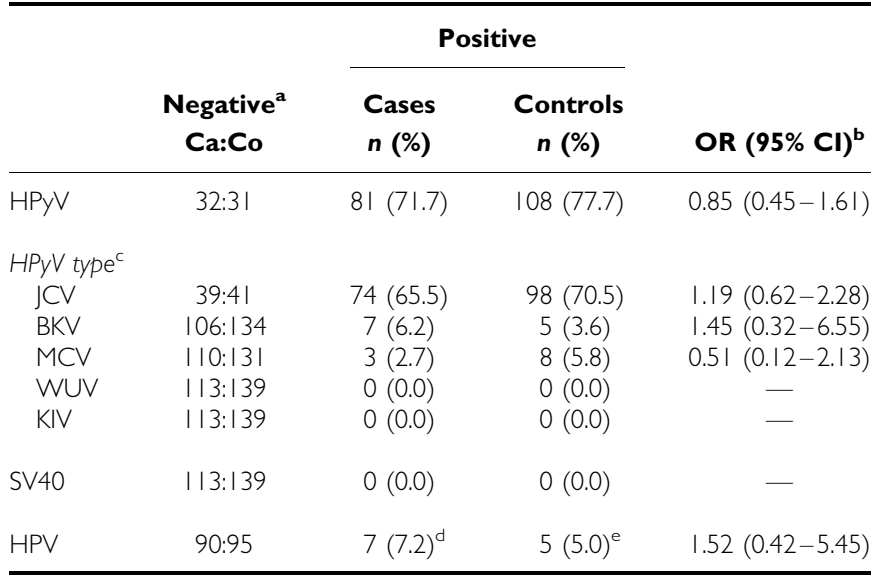

${ }^{a}$ Reference category. ${ }^{b}$ Estimated from unconditional logistic regression and adjusted for sex, age, education, tobacco smoking, and alcohol drinking. 'Including multiple infection with JCV-BKV in one case, and multiple infection with JCV-MCV in two cases and three controls. Including HPV3I, 35, 45, 58, 70 and HPV56 in two subjects. Including HPV33, 5I, 58 and HPV56 in two subjects.

associated with TCB risk (OR for current $v s$ never smoking $=9.15$; 95\% CI: 3.92-21.37), with a significant risk trend for number of cigarettes $(P<0.01)$, while no significant association was found with alcohol consumption.
Table 3 Detection of human polyomavirus (HPyV) DNA in the urine according to age and tumour characteristics among II3 bladder cancer cases

\begin{tabular}{|c|c|c|c|}
\hline & \multicolumn{2}{|c|}{ HPyV DNA } & \multirow[b]{2}{*}{ Fisher test } \\
\hline & $\begin{array}{c}\text { Positive } \\
\text { n (\%) }\end{array}$ & $\begin{array}{c}\text { Negative } \\
n(\%)\end{array}$ & \\
\hline Age (years) & & & $P=0.39$ \\
\hline$<65$ & $27(65.9)$ & $14(34.1)$ & \\
\hline $65-74$ & $34(79.1)$ & $9(20.9)$ & \\
\hline $\begin{array}{l}\geqslant 75 \\
\chi^{2} \text { for trend }\end{array}$ & $20(69.0)$ & $9(31.0)$ & \\
\hline Histological type & & & $P=1.00$ \\
\hline Transitional cell carcinoma & $18(72.0)$ & $7(28.0)$ & \\
\hline Papillary transitional cell carcinoma & $63(71.6)$ & $25(28.4)$ & \\
\hline Grade & & & $P=1.00$ \\
\hline Well differentiated & | | (73.3) & $4(26.7)$ & \\
\hline Moderately differentiated & $28(71.8)$ & I | (28.2) & \\
\hline Poorly differentiated/undifferentiated & $40(71.4)$ & $16(28.6)$ & \\
\hline Unknown & $2(66.7)$ & I (33.3) & \\
\hline Stage & & & $P=0.50$ \\
\hline 0 & $50(74.6)$ & $17(25.4)$ & \\
\hline 1 & $15(75.0)$ & $5(25.0)$ & \\
\hline II or worse & $15(62.5)$ & $9(37.5)$ & \\
\hline Unknown & I (50.0) & I (50.0) & \\
\hline
\end{tabular}

Human polyomavirus-positivity in urine was similar in cases $(71.7 \%)$ and controls $(77.7 \%)(\mathrm{OR}=0.85 ; 95 \% \mathrm{CI}: 0.45-1.61)$ (Table 2). JCV was the most frequently detected HPyV (65.5\% and $70.5 \%$ in cases and controls, respectively), and it was associated with an OR of 1.19 (95\% CI: $0.62-2.28)$. Positivity for BKV and MCV was rarer but not significantly different in TCB cases and controls. Corresponding CIs were, however, broad. WUV, KIV, and SV40 were never detected. Mucosal HPV DNA was detected in seven cases (including HPV31, 35, 45, 58, 70 and HPV56 in two cases) and five controls (including HPV33, 51, 58 and HPV56 in two controls) $(\mathrm{OR}=1.52 ; 95 \% \mathrm{CI}: 0.42-5.45)$ (Table 2).

Table 3 shows age, histological type, grade, and stage among TCB cases by HPyV-positivity. The majority of TCB cancers in our study showed papillary features and were detected at stage 0 (zero). No significant differences in tumour characteristics were found between $\mathrm{HPyV}$-positive and HPyV-negative cases.

Factors associated with HPyV-positivity are shown in the combination of cases and controls (Table 4) since no relationship had emerged between HPyV-positivity and case/control status. Human polyomavirus-positivity did not vary by age group, education level, and drinking habit. Conversely, HPyV-positivity was lower in women than men $(\mathrm{OR}=0.29 ; 95 \% \mathrm{CI}: 0.14-0.57)$ and among current $(\mathrm{OR}=0.32 ; 95 \% \mathrm{CI}: 0.13-0.79)$ and former $(\mathrm{OR}=0.34 ; 95 \% \mathrm{CI}: 0.13-0.90)$ smokers than never smokers. The risk of HPyV-positivity was also inversely related to the number of siblings (OR for $0-1 v s \geqslant 6$ siblings $=2.82 ; 95 \% \mathrm{CI}$ : 1.07-7.41; $P$ for trend $=0.03$ ) (Table 4). All associations with HPyV-positivity were confirmed when ORs were additionally adjusted for tobacco smoking, as appropriate, and when analyses were restricted to TCB cases or controls, and men or women (data not shown).

\section{DISCUSSION}

Our present case-control study confirms that DNA from HPyV, notably JCV, BKV, and MCV, is frequently detectable in the urine of immunocompetent individuals, but it is found in similar 
Table 4 Odds ratios (ORs) for the presence of human polyomavirus (HPyV) DNA in urine and corresponding 95\% confidence intervals (Cls) according to selected variables among 252 study subjects

\begin{tabular}{|c|c|c|c|}
\hline & \multicolumn{2}{|c|}{ HPyV DNA } & \multirow[b]{2}{*}{ OR $(95 \% \mathrm{Cl})^{\mathrm{a}}$} \\
\hline & $\begin{array}{c}\text { Positive } \\
\text { n (\%) }\end{array}$ & $\begin{array}{c}\text { Negative } \\
n(\%)\end{array}$ & \\
\hline \multicolumn{4}{|l|}{ Age (years) } \\
\hline$<65$ & $69(76.7)$ & 21 (23.3) & $1^{b}$ \\
\hline $65-74$ & $79(76.0)$ & $25(24.0)$ & $0.93(0.47-1.84)$ \\
\hline $\begin{array}{l}\geqslant 75 \\
\chi^{2} \text { for trend }\end{array}$ & 41 (70.7) & $17(29.3)$ & $\begin{array}{c}1.00(0.45-2.21) \\
0.00 ; P=0.97\end{array}$ \\
\hline \multicolumn{4}{|l|}{ Sex } \\
\hline Men & $165(79.7)$ & $42(20.3)$ & $1^{b}$ \\
\hline Women & $24(53.3)$ & $21(46.7)$ & $0.29(0.14-0.57)$ \\
\hline \multicolumn{4}{|l|}{ Education (years) } \\
\hline$<7$ & $92(73.6)$ & $33(26.4)$ & $1^{\mathrm{b}}$ \\
\hline $7-11$ & 65 (77.4) & $19(22.6)$ & $1.16(0.58-2.35)$ \\
\hline$\geqslant 12$ & $32(74.4)$ & II (25.6) & $0.94(0.39-2.26)$ \\
\hline$\chi^{2}$ for trend & & & $0.00 ; P=1.00$ \\
\hline \multicolumn{4}{|l|}{ Smoking habit } \\
\hline Never & $50(83.3)$ & $10(16.7)$ & $1^{\mathrm{b}}$ \\
\hline Former & $95(73.6)$ & $34(26.4)$ & $0.34(0.13-0.90)$ \\
\hline Current & $44(69.8)$ & $19(30.2)$ & $0.32(0.13-0.79)$ \\
\hline \multicolumn{4}{|c|}{ Drinking habit (drinks/week) } \\
\hline$<21$ & $75(70.0)$ & $32(30.0)$ & $1^{\mathrm{b}}$ \\
\hline$\geqslant 21$ & $114(78.1)$ & $31(21.9)$ & $1.07(0.55-2.06)$ \\
\hline \multicolumn{4}{|c|}{ Number of siblings ${ }^{c}$} \\
\hline$\geqslant 6$ & $26(61.9)$ & $16(38.1)$ & $1^{\mathrm{b}}$ \\
\hline $4-5$ & $45(75.0)$ & $15(25.0)$ & $1.65(0.68-4.01)$ \\
\hline $2-3$ & $70(76.9)$ & $21(23.1)$ & $2.29(0.97-5.40)$ \\
\hline $0-1$ & $47(81.0)$ & II (19.0) & $2.82(1.07-7.41)$ \\
\hline$\chi^{2}$ for trend & & & $4.92 ; P=0.03$ \\
\hline
\end{tabular}

aEstimated from unconditional logistic regression and adjusted for case-control status, sex, age, as appropriate. 'Reference category. 'Sum does not add up to the total because of one missing value.

proportions in TCB cases and controls. Human papillomavirus DNA was seldom detected but, as for $\mathrm{HPyV}$, its presence was not significantly associated to TCB risk. No difference in HPyVpositivity among TCB cases was found by age group, histological type, tumour grade, or stage.

Seroprevalence of antibodies against BKV and JCV in adults was reported to be, respectively, over $90 \%$ and 50\% (Knowles, 2006). After primary infection in childhood or adolescence, BKV and JCV are known to persist in urothelial cells of the kidney, ureter, and bladder although it is unclear whether these viruses enter a latent state or maintain a low level of viral gene expression and replication at these sites (Jiang et al, 2009). Intermittent replication is supported by periodic viral excretion in the urine. Our findings agree with previous reports of JCV and BKV viruria of $20-60 \%$ and 5\%, respectively, among immunocompetent individuals (Knowles, 2006).

An involvement of $\mathrm{HPyV}$ in bladder cancer aetiology had been suggested by a few case series that showed high prevalence of various markers of $\mathrm{HPyV}$, mainly $\mathrm{BKV}$, in TCB (Fioriti et al, 2003; Weinreb et al, 2006; Abend et al, 2009; Maginnis and Atwood, 2009). Human polyomaviruses can transform rodent and human cells and are carcinogenic in animal models (Barbanti-Brodano et al, 2006). In addition, they encode a tumour ( $\mathrm{T}$ ) antigen protein complex that targets the product of several tumour suppressor genes (Moore and Chang, 2010). Although they showed a significant difference between cases and controls, Weinreb et al (2006), in a previous investigation on urine samples, reported prevalences of BKV (9.8\% among TCB cases and 3.1\% among controls) similar to those reported in our study $(6.2 \%$ and $3.6 \%$, respectively). Rollison et al (2007) reported that BKV DNA was found in $5.4 \%$ of 70 patients with TCB but T-antigen expression was not demonstrated by immunohistochemistry in BKV DNApositive cancer tissue. Roberts et al (2008) used immunohistochemistry to assess the prevalence of T-antigen from any HPyV in TCB. None of the 20 consecutive non-renal transplant patients was positive for T-antigen. Out of eight TCBs in renal transplant patients, one showed a strong nuclear staining with T-antigen, in agreement with another single-case report from a renal transplant patient (Geetha et al, 2002). In a case-control study nested in a cohort, there was no significant difference in seroprevalence or titre of antibodies against BKV between 9 TCB cases and 45 controls (Newton et al, 2005). Very little is known on TCB and $\mathrm{HPyV}$ other than BKV and there is no clear evidence of an association of $\mathrm{HPyV}$ with any human cancer except for Merkel cell tumour (Moore and Chang, 2010).

JCV and BKV are believed to be transmitted early in life through respiratory or urino-oral mode but risk factors for acquisition or reactivation of the infection, other than immunosuppression, have never been reported (Jiang et al, 2009). In our study, HPyVpositivity did not vary by age group but it was significantly less frequent in women than men and in current or former smokers than never smokers. It was also inversely correlated to family size although not to education level. The reasons for the lower frequency of HPyV-positivity in women and smokers and former smokers are unclear but our present findings were not modified by inclusion of TCB cases and controls or controls only or stratification by smoking or sex. As we relied on HPyV DNA presence in urine, rather than serum anti-HPyV antibodies, the risk factors that we identified might be associated with acquisition, persistence, or reactivation of $\mathrm{HPyV}$ infection.

No association between HPV-positivity and TCB was found in our study. Notably, no HPV16 or 18, the types that greatly predominate in known HPV-related cancers (IARC, 2007), were detected among TCB cases. A large number of case series have been published on the presence of mucosal HPV types in TCB (IARC, 2007; Cai et al, 2011; Shigehara et al, 2011; Yavuzer et al, 2011). The prevalence of HPV DNA varied widely (from $0 \%$ to $80 \%$ ) in PCR-based studies (IARC, 2007). A case-control study showed a significantly higher prevalence of HPV DNA in the urine of 78 TCB cases (46\%) compared with 59 controls (14\%) who had undergone transurethral resection of the prostate for benign prostatic hyperplasia (Cai et al, 2011). Contamination from the lower genital tract during the acquisition of urine or exfoliated cells from the bladder is, however, of special concern in these studies on account of the frequent presence of HPV infection in the lower genital tract (IARC, 2007).

Urine samples have limited value to evaluate the presence of HPV infection in the external male genitalia as the yield of $\beta$ globin and HPV DNA is worse than in exfoliated cell samples from the glans, corona, prepuce, and shaft of the penis (Dunne et al, 2006). The aim of our study was, however, to assess the presence of HPV infection in the bladder and, therefore, sampling of exfoliated cells from the male external genitalia would have been clearly inappropriate. On the other hand, it was impossible to use more invasive sampling procedures (e.g., bladder tissue biopsies), as they would have been impossible to obtain from the control group. The restriction of our present study to $\beta$-globin-positive urine samples should have at least in part obviated sample quality problems.

Unique strengths of our present study include the availability of a well-comparable control group and of a wide range of information on lifestyle risk factors for TCB. In addition, our study was the first one to rely on highly sensitive and specific PCR assays that allowed the detection of DNA of five HPyV and SV40 and all the most common mucosal HPV types. An important 
weakness of our present study is the limited number of subjects involved. Confidence intervals around our ORs were, therefore, broad and did not allow to rule out the presence of positive association, especially with BKV and HPV. Another major weakness was lack of further assessment of viral DNA presence or immunohistochemistry findings in cancer tissue samples.

In conclusion, our small study does not support an involvement of $\mathrm{HPyV}$ or HPV infection in the aetiology of TCB in immunocompetent individuals. Lower detection of HPyV DNA in women and smokers might be related to differences in either acquisition or persistence and reactivation of the infection.

\section{ACKNOWLEDGEMENTS}

We are deeply grateful to Drs A Garbeglio, D Maruzzi, and A Marin (Urology Unit, General Hospital, Pordenone) for patient's recruitment. This study was supported partially by grants to M Tommasino from La Ligue Contre le Cancer (Comités du Rhône, Drôme and Savoie) and Association pour la Recherche sur le Cancer (ARC). NS was supported by a grant from Higher Education Commission (HEC) of Pakistan. This study was also supported by the Italian Association for Research on Cancer (AIRC).

\section{REFERENCES}

Abend JR, Jiang M, Imperiale MJ (2009) BK virus and human cancer: innocent until proven guilty. Semin Cancer Biol 19: 252-260

Barbanti-Brodano G, Sabbioni S, Martini F, Negrini M, Corallini A, Tognon M (2006) BK virus, JC virus and Simian Virus 40 infection in humans, and association with human tumors. Adv Exp Med Biol 577: 319-341

Bedwani R, Renganathan E, El Kwhsky F, Braga C, Abu Seif HH, Abul AT, Zaki A, Franceschi S, Boffetta P, La Vecchia C (1998) Schistosomiasis and the risk of bladder cancer in Alexandria, Egypt. Br J Cancer 77: 1186-1189

Breslow NE, Day NE (1980) Statistical Methods in Cancer Research, Vol. I The Analysis of Case-Control Studies. IARC Scientific Publications No. 32. International Agency for Research on Cancer: Lyon

Cai T, Mazzoli S, Meacci F, Nesi G, Geppetti P, Malossini G, Bartoletti R (2011) Human papillomavirus and non-muscle invasive urothelia bladder cancer: potential relationship from a pilot study. Oncol Rep 25: $485-489$

D’Avanzo B, La Vecchia C, Katsouyanni K, Negri E, Trichopoulos D (1996) Reliability of information on cigarette smoking and beverage consumption provided by hospital controls. Epidemiology 7: 312-315

Dunne EF, Nielson CM, Stone KM, Markowitz LE, Giuliano AR (2006) Prevalence of HPV infection among men: a systemic review of the literature. J Infect Dis 194: 1044-1057

Ferlay J, Shin HR, Bray F, Forman D, Mathers C, Parkin DM (2010) Estimates of worldwide burden of cancer in 2008: GLOBOCAN 2008. Int J Cancer 127: 2893-2917

Fioriti D, Pietropaolo V, Dal Forno S, Laurenti C, Chiarini F, Degener AM (2003) Urothelial bladder carcinoma and viral infections: different association with human polyomaviruses and papillomaviruses. Int $J$ Immunopathol Pharmacol 16: $283-288$

Geetha D, Tong BC, Racusen L, Markowitz JS, Westra WH (2002) Bladder carcinoma in a transplant recipient: evidence to implicate the BK human polyomavirus as a causal transforming agent. Transplantation 73: $1933-1936$

Gheit T, Landi S, Gemignani F, Snijders PJ, Vaccarella S, Franceschi S, Canzian F, Tommasino M (2006) Development of a sensitive and specific assay combining multiplex PCR and DNA microarray primer extension to detect high-risk mucosal human papillomavirus types. J Clin Microbiol 44: $2025-2031$

IARC (2007) Monographs on the Evaluation of Carcinogenic Risks to Humans Volume 90: Human Papillomaviruses. International Agency for Research on Cancer: Lyon. Monographs on the evaluation of carcinogenic risk to humans

Jiang M, Abend JR, Johnson SF, Imperiale MJ (2009) The role of polyomaviruses in human disease. Virology 384: 266-273

Johne R, Buck CB, Allander T, Atwood WJ, Garcea RL, Imperiale MJ, Major EO, Ramqvist T, Norkin LC (2011) Taxonomical developments in the family polyomaviridae. Arch Virol 156: 1627-1634
Knowles WA (2006) Discovery and epidemiology of the human polyomaviruses BK virus (BKV) and JC virus (JCV). Adv Exp Med Biol 577: $19-45$

La Vecchia C, Negri E, D’Avanzo B, Savoldelli R, Franceschi S (1991) Genital and urinary tract diseases and bladder cancer. Cancer Res 51: $629-631$

Maginnis MS, Atwood WJ (2009) JC virus: an oncogenic virus in animals and humans? Semin Cancer Biol 19: $261-269$

Moore PS, Chang Y (2010) Why do viruses cause cancer? Highlights of the first century of human tumour virology. Nat Rev Cancer 10: $878-889$

Newton R, Ribeiro T, Casabonne D, Alvarez E, Touze A, Key T, Coursaget P (2005) Antibody levels against BK virus and prostate, kidney and bladder cancers in the EPIC-Oxford cohort. Br J Cancer 93: 1305-1306

Roberts IS, Besarani D, Mason P, Turner G, Friend PJ, Newton R (2008) Polyoma virus infection and urothelial carcinoma of the bladder following renal transplantation. Br J Cancer 99: 1383-1386

Rollison DE, Sexton WJ, Rodriguez AR, Kang LC, Daniel R, Shah KV (2007) Lack of BK virus DNA sequences in most transitional-cell carcinomas of the bladder. Int J Cancer 120: $1248-1251$

Schmitt M, Dondog B, Waterboer T, Pawlita M, Tommasino M, Gheit T (2010) Abundance of multiple high-risk human papillomavirus (HPV) infections found in cervical cells analyzed by use of an ultrasensitive HPV genotyping assay. J Clin Microbiol 48: 143-149

Scuda N, Hofmann J, Calvignac-Spencer S, Ruprecht K, Liman P, Kuhn J, Hengel H, Ehlers B (2011) A novel human polyomavirus closely related to the African green monkey-derived lymphotropic polyomavirus. J Virol 85: $4586-4590$

Shigehara K, Sasagawa T, Kawaguchi S, Nakashima T, Shimamura M, Maeda Y, Konaka H, Mizokami A, Koh E, Namiki M (2011) Etiologic role of human papillomavirus infection in bladder carcinoma. Cancer 117: 2067-2076

Silverman DT, Devesa SS, Moore LE, Rothman N (2006) Bladder cancer. In: Schottenfeld D, Fraumeni Jr JF (eds), Cancer Epidemiology and Prevention, 3rd edn, pp 1101 -1127. Oxford University Press: New York Vajdic CM, McDonald SP, McCredie MR, van Leeuwen MT, Stewart JH, Law M, Chapman JR, Webster AC, Kaldor JM, Grulich AE (2006) Cancer incidence before and after kidney transplantation. JAMA 296: $2823-2831$

Weinreb DB, Desman GT, Amolat-Apiado MJ, Burstein DE, Godbold Jr JH, Johnson EM (2006) Polyoma virus infection is a prominent risk factor for bladder carcinoma in immunocompetent individuals. Diagn Cytopathol 34: $201-203$

Yavuzer D, Karadayi N, Salepci T, Baloglu H, Bilici A, Sakirahmet D (2011) Role of human papillomavirus in the development of urothelial carcinoma. Med Oncol 28: 919-923

This work is published under the standard license to publish agreement. After 12 months the work will become freely available and the license terms will switch to a Creative Commons Attribution-NonCommercial-Share Alike 3.0 Unported License. 